\title{
Synergistic combination therapy with cotylenin A and vincristine in multiple myeloma models
}

\author{
TSUTOMU TAKAHASHI, YOSHIO HONMA, TAKAAKI MIYAKE, KOJI ADACHI, SAKI TAKAMI, \\ MASAHIRO OKADA, SATOSHI KUMANOMIDOU, FUMIYOSHI IKEJIRI, YUMI JO, CHIE ONISHI, \\ KOSHI KAWAKAMI, ICHIRO MORIYAMA, MASAYA INOUE, JUNKO TANAKA and JUNJI SUZUMIYA
}

Department of Oncology/Hematology, Shimane University Hospital, Izumo-shi, Shimane, Japan

Received December 5, 2014; Accepted January 22, 2015

DOI: $10.3892 /$ ijo.2015.2882

\begin{abstract}
Multiple myeloma is a malignant proliferative disease of plasma cells in the bone marrow and remains largely incurable. Cotylenin A, a fusicoccane diterpene glycoside with a complex sugar moiety, was isolated as a plant-growth regulator. Cotylenin A has been shown to inhibit the growth of various cancer cells. Herein, we examined the anti-myeloma effects of cotylenin A using five human myeloma cell lines (RPMI-8226, KMS-11, KMS-26, KMS-12 PE and KMS-12 BM) and xenografts in immunodeficient mice. Cotylenin A and vincristine synergistically inhibited the growth and induced apoptosis in myeloma cells. While other microtubule-disturbing agents also showed co-operative effects with cotylenin A, other anticancer agents, such as doxorubicin, cisplatin, camptothecin, methotrexate, gemcitabine and 5-fluorouracil, did not show such co-operation with cotylenin A. These differences might be attributed to the effects on autophagic responses. Combined treatment with cotylenin A and vincristine induced autophagy (formation of LC3-II and degradation of p62 protein). However, doxorubicin did not enhance the autophagy induced by cotylenin A. A colony-forming assay indicated that the combined treatment with cotylenin A and vincristine more effectively suppressed the formation of large colonies, which have higher self-renewal activity than vincristine alone. Expression of pluripotency-associated transcription factor Sox 2 mRNA in RPMI-8226 myeloma cells was significantly suppressed by treatment with cotylenin A. Combined treatment with cotylenin A and vincristine significantly inhibited the growth of KMS-26 myeloma cells as xenografts. Our results suggest that the combination of cotylenin A and vincristine may have therapeutic value. Recently, it was reported that cotylenin A modulates the 14-3-3 intracellular signaling pathway. The 14-3-3 proteins may be novel targets in treating myeloma.
\end{abstract}

Correspondence to: Dr Tsutomu Takahashi, Shimane University Hospital, 89-1 Enya-chou, Izumo-shi, Shimane 693-8501, Japan E-mail: ben2106t@med.shimane-u.ac.jp

Key words: myeloma cell, cotylenin A, vincristine, stemness, xenograft
However, our study could not explain how the sensitization to vincristine is related to the effects of cotylenin A on the 14-3-3 signaling pathway and further studies will be needed.

\section{Introduction}

Multiple myeloma is a malignant proliferative disease of plasma cells in the bone marrow. While drugs such as lenalidomide and bortezomib have improved survival, myeloma remains largely incurable. Efforts are underway to optimize existing chemotherapeutic strategies and discover new agents. It is important to control the disease in the long term while maintaining the patient's quality of life because it is still difficult to cure. The development of less-cytotoxic agents would be desirable for this purpose.

Cotylenin A, which has a diterpenoid tricarbocyclic skeleton, has been shown to induce the differentiation of myeloid leukemia cell lines and leukemic cells isolated from acute myeloid leukemia patients in primary culture (1-3). Administration of cotylenin A significantly prolonged the survival of mice that had been inoculated with retinoidsensitive and -resistant NB4 cells, and no appreciable adverse effects were observed in the experiments (4).

Combined treatment with IFN $\alpha$ and cotylenin A preferentially induced apoptosis in human lung cancer cells while sparing normal lung epithelial cells and significantly inhibited the growth of human lung cancer cells as xenografts without apparent adverse effects, suggesting that this combination may have therapeutic value in treating human cancer (5-7). These findings suggest that cotylenin A may be useful in the therapy for leukemia and some other malignancies.

In the present study, we examined the antitumor effects of cotylenin A and identified drugs that could be administered in combination with cotylenin A to inhibit the growth of myeloma cells to develop a novel therapeutic strategy against multiple myeloma.

\section{Materials and methods}

Cells and culture. Human multiple myeloma cell lines RPMI8226, KMS-11, KMS-26, KMS-12 PE and KMS-12 BM were obtained from JCRB Cell Bank (Osaka, Japan), and cultured in RPMI-1640 supplemented with $10 \%$ fetal bovine serum. 
Matrigel-coated dishes were prepared according to the manufacturer's instructions (BD Biosciences, San Jose, CA, USA).

Materials. Cotylenin A was purified from a stock ethyl acetate extract obtained from the culture filtrate of Cladosporium fungus sp. 501-7W by flash chromatography on silica gel with $>99 \%$ purity (8). Vincristine and other anticancer agents, 3-(4,5-di-methylthiazol-2-yl)-2,5-diphenyltetrazolium bromide (MTT), and propidium iodide were purchased from Sigma-Aldrich (St. Louis, MO, USA). Anti-XIAP, antisurvivin and anti-LC3 monoclonal antibodies were purchased from Cell Signaling Technology (Danvers, MA, USA). AntiP62 monoclonal antibody was obtained from MBL (Nagoya, Japan).

Assay of cell growth. The cells were seeded at $1 \times 10^{5}$ cells $/ \mathrm{ml}$ in a 24-well multidish. After culture with or without the test compounds for indicated times, viable cells were examined by a modified MTT assay (9).

Annexin $V$ binding assay. Cells were labeled with PE-labeled Annexin V (BD Biosciences) for $30 \mathrm{~min}$ on ice, as described previously (10). After staining, cells were washed and analyzed by flow cytometry (BD FACSCalibur, San Jose, CA, USA).

Flow cytometric analysis of cell cycle distribution. The cell cycle was analyzed using propidium iodide-stained nuclei (11). The histogram of DNA content was analyzed by flow cytometry (BD FACSCalibur) using CellQuest software (BD Immunocytometry Systems, San Jose, CA, USA) to determine the cell cycle distribution (sub-G1, G1, S and G2/M).

Protein profiler array. RPMI-8226 cells were treated with or without cotylenin A and/or vincristine for $48 \mathrm{~h}$. All immunodetection steps were performed using a Proteome Profiler Array (R\&D Systems, Minneapolis, MN, USA) in accordance with the manufacturer's instructions. Briefly, the cells were collected and lysed in lysis buffer. The array was incubated overnight with the diluted lysates $(500 \mu \mathrm{g} / 250 \mu \mathrm{l})$ at $4^{\circ} \mathrm{C}$ on a rocking platform shaker. Primary (reconstituted detection antibody cocktail) and secondary [streptavidinhorseradish peroxidase (HRP) (1:2000)] antibodies were added to each array.

Western blot analysis. Cells were packed after being washed with cold phosphate-buffered saline (PBS) and then lysed at a concentration of $1 \times 10^{7}$ cells $/ \mathrm{ml}$ in lysis buffer (Wako, Osaka, Japan). Equal amounts of protein were separated on $10 \%$ SDS-polyacrylamide gels. The proteins were electrophoresed on gels and transferred to an Immobilon-P membrane (Millipore, Bedford, MA, USA) using rabbit anti-XIAP (1:1000) and rabbit anti-survivin (1:1000) antibodies. All Western blots shown are representative of at least 3 independent experiments.

Transwell chamber invasion assay. The invasiveness of RPMI-8226 cells was evaluated by a transwell chamber assay. Matrigel (50 $\mu \mathrm{g} / \mathrm{ml}, \mathrm{BD}$ Biosciences) was melted at $4^{\circ} \mathrm{C}$, and diluted to $1: 8$ by serum-free RPMI-1640 medium. The upper side of the polycarbonate filter of the Transwell chamber was coated with matrigel. Cells $\left(2 \times 10^{5}\right)$ were suspended in $800 \mu 1$ of serum-free medium that contained $1 \mathrm{mg} / \mathrm{ml}$ bovine serum albumin to maintain the osmotic pressure, and placed in the upper chamber. The lower chamber was filled with $10 \%$ serum-medium $(1000 \mu \mathrm{l})$. Cells were then cultured for $24 \mathrm{~h}$ at $37^{\circ} \mathrm{C}$ in $5 \% \mathrm{CO}_{2}$. Cells on the upper surface of the filter were removed using a cotton swab. The invading cells on the lower surface of the filter were fixed with formaldehyde (4\%) and stained with $0.1 \%$ crystal violet in $2 \%$ methanol. Invasiveness was determined by counting cells in five microscopic fields per well, and the extent of invasion was expressed as the average number of cells per microscopic field.

Colony-forming assay. Cells ( $1 \times 10^{4}$ per dish) were plated into $1.1 \mathrm{ml}$ of a semisolid methylcellulose medium with $0.8 \%$ methylcellulose and $20 \%$ fetal bovine serum in triplicate for 14 days. A solution of $0.2 \mathrm{ml}$ of PBS containing various concentrations of cotylenin A or vincristine was added to the semisolid medium. Colonies were photographed under an inverted microscope. Colonies in enlarged photographs were measured and counted. Colonies were classified as large $(>0.7 \mathrm{~mm}$ in diameter), medium $(0.4-0.7 \mathrm{~mm})$ or small (0.2-0.4 mm).

Reverse transcription-polymerase chain reaction (RT-PCR). Total RNA was extracted from cells using TRI reagent (SigmaAldrich). Total RNA (1 $\mu \mathrm{g})$ was converted to first-strand cDNA primed with random hexamer in a reaction volume of $20 \mu \mathrm{l}$ using an RNA PCR kit (Takara Bio, Tokyo, Japan), and $4 \mu \mathrm{l}$ of this reaction mixture was used as a template in the polymerase chain reaction (9). The primers used were as previously described (12).

Transplantation of myeloma cells into SCID mice and treatment. Six-week-old female (Fox Chase SCID C.B-17/Icr-scid Jcl) mice were subcutaneously inoculated with $6 \times 10^{6} \mathrm{KMS}-26$ cells. The adjusted $6 \times 10^{7}$ cells $/ \mathrm{ml}$ were mixed with an equal volume of Matrigel (BD Biosciences) and $0.2 \mathrm{ml}$ of the mixture was subcutaneously injected into the lower back of each animal using a 26-gauge needle. Mice were given intraperitoneal injections of $0.2 \mathrm{ml}$ of PBS with $0.5 \mathrm{mg} / \mathrm{kg}$ vincristine and/or $5 \mathrm{mg} / \mathrm{kg}$ cotylenin A three times per week for 3 weeks. The first treatment was given 4 days after the inoculation of tumor cells. Tumor volume was measured with vernier calipers. We performed experiments according to national legislation on laboratory animal protection and our protocol was approved by the animal ethics committee of Shimane University.

Statistical analysis. Pairs of data were compared using Student's t-test. For the experiment in vivo, the significance of differences among the four groups was assessed using a one-way analysis of variance and the Kruskal-Wallis test. P-values of $<0.05$ were considered to reflect statistical significance.

\section{Results}

Combined effects of cotylenin A and various drugs on the growth of myeloma cells. Since IFN $\alpha$ has been shown to have beneficial effects in the treatment of multiple myeloma $(13,14)$, 


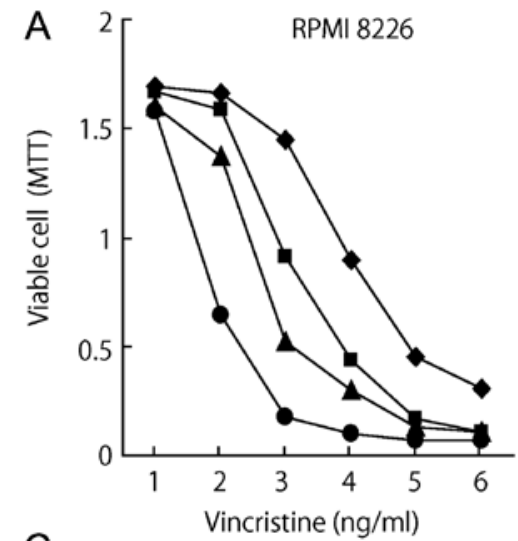

B
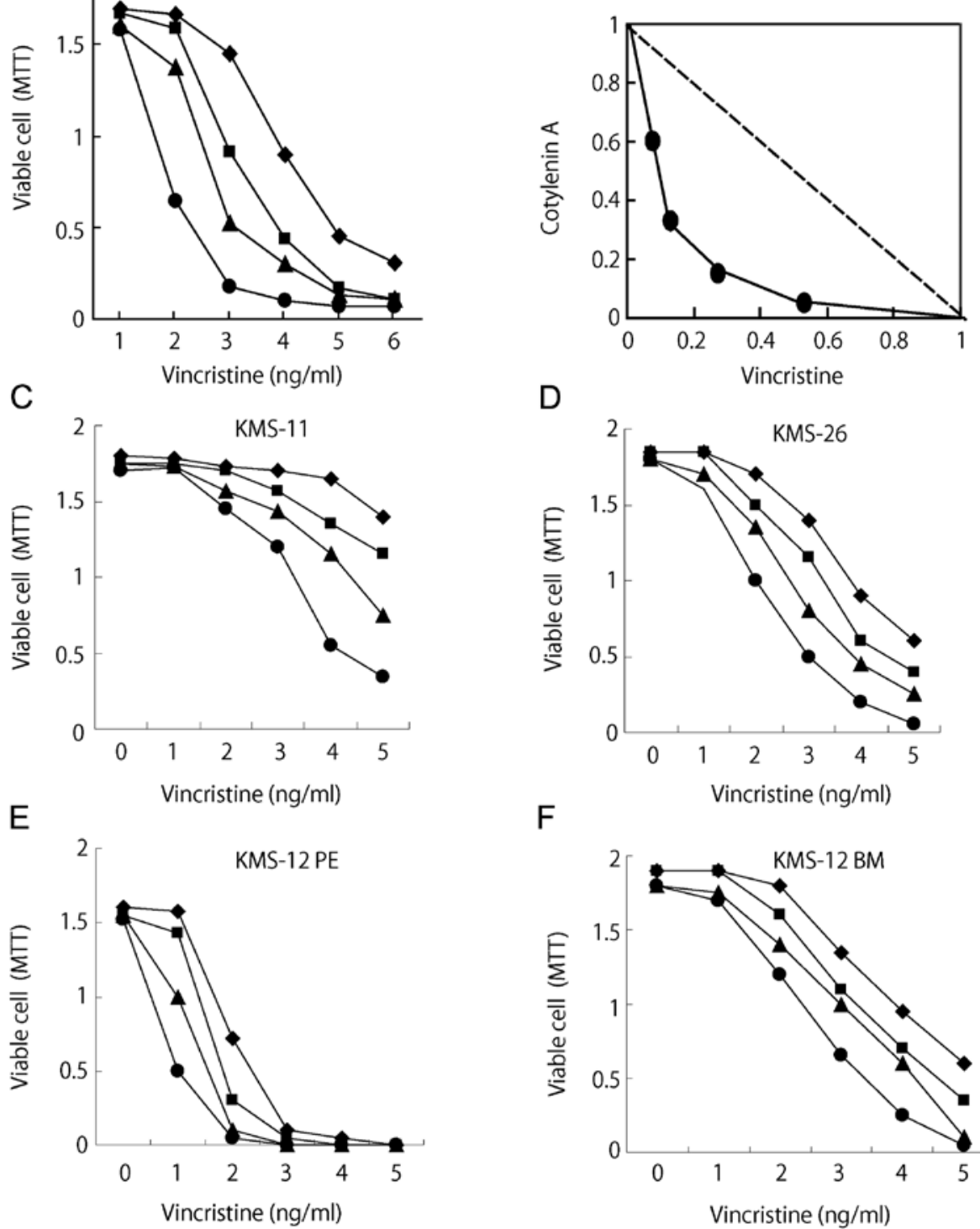

$\mathrm{F}$

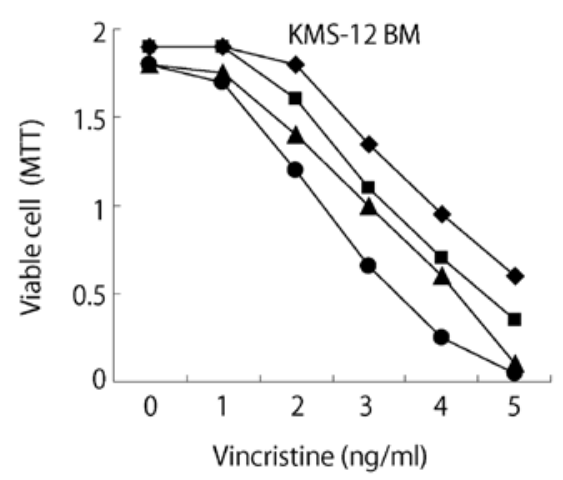

Figure 1. Combined effects of cotylenin A and vincristine on the growth of human myeloma cells. RPMI-8226 (A), KMS-11 (C), KMS-26 (D), KMS-12 PE (E), and KMS-12 BM (F) cells were cultured with various concentrations of vincristine in the presence of $0(\bullet), 1(\bullet), 2(\Delta)$, or $4(\bullet) \mu \mathrm{g} / \mathrm{ml}$ cotylenin A for 5 days (B) Classic isobologram at $\mathrm{IC}_{50}$ : cotylenin A plus vincristine in RPMI-8226 cells. Isoboles for the combination of cotylenin A with vincristine were isoeffective $\left(\mathrm{IC}_{50}\right)$ for inhibiting proliferation of the cells. The dashed line indicates the zero interaction of the isobole. Cells $\left(3 \mathrm{x} 10^{4}\right.$ cells $\left./ \mathrm{ml}\right)$ were treated with cotylenin $\mathrm{A}$ and vincristine for 5 days. Values are the means of three separate experiments. $\mathrm{IC}_{50}$, the concentration of the drug required for $50 \%$ inhibition of cell growth. The values represent the means of three determinations.

and combined treatment with cotylenin A and IFN $\alpha$ synergistically inhibited growth both in vitro and in vivo in various human cancer cells $(6,7)$, multiple myeloma might be a reasonable target for combined treatment with cotylenin A and IFN $\alpha$. Therefore, we examined the anti-proliferative effects of cotylenin A and IFN $\alpha$ in 5 myeloma cell lines. RPMI-8226, KMS-12 PE and KMS-26 cells were highly sensitive to the combined treatment. However, KMS-12 BM cells did not respond to IFN $\alpha$ even in the presence of cotylenin $\mathrm{A}$, and KMS-11 cells were less sensitive to the combined treatment. These results suggest that this treatment may be useful only in certain patients with multiple myeloma.

Next, we screened various anticancer agents with small molecules to identify the most potent drug with respect to its co-operative effect with cotylenin A on the growth of multiple myeloma cells. To measure the effects of various drugs on the growth of myeloma RPMI-8226 cells, the number of viable cells was determined by the MTT assay after 6 days of exposure to various concentrations of drugs with or without $2 \mu \mathrm{g} / \mathrm{ml}$ of cotylenin A. The growth-inhibiting effects of the drugs were examined by determining the concentrations of drugs required to reduce the cell number to one-half of that in untreated cells $\left(\mathrm{IC}_{50}\right)$. While the sensitivity to anticancer agents, such as doxorubicin, camptotecin, cisplatin, 5-fluorouracil, methotrexate or gemcitabine, was not affected by cotylenin A, the sensitivity to vincristine and other microtubule-disturbing agents was significantly enhanced (Table I).

Cotylenin A had synergistic effects with vincristine (Fig. 1A) and the results were confirmed by an isobologram analysis (15). Fig. 1B shows isoboles for the combination 


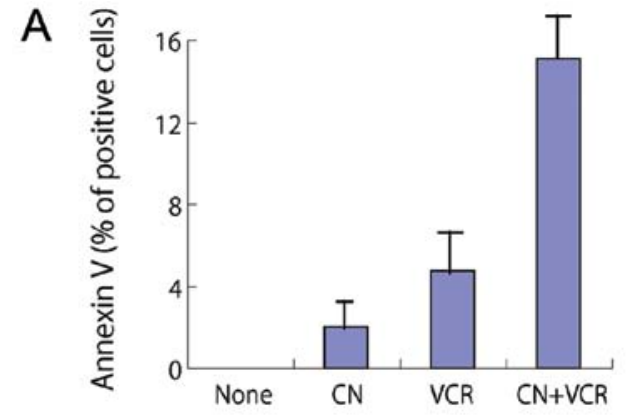

C

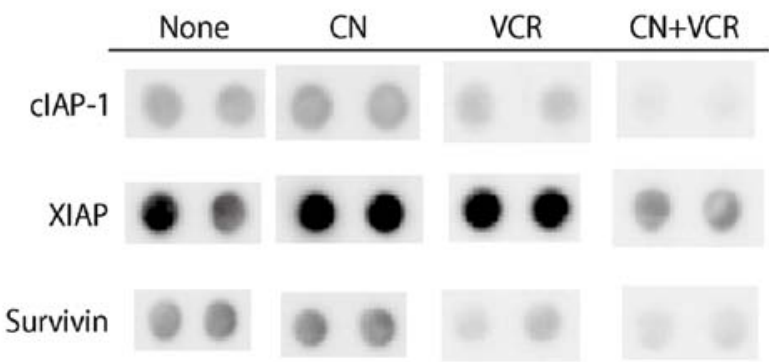

B

Procaspase-3

Cleaved caspase-3
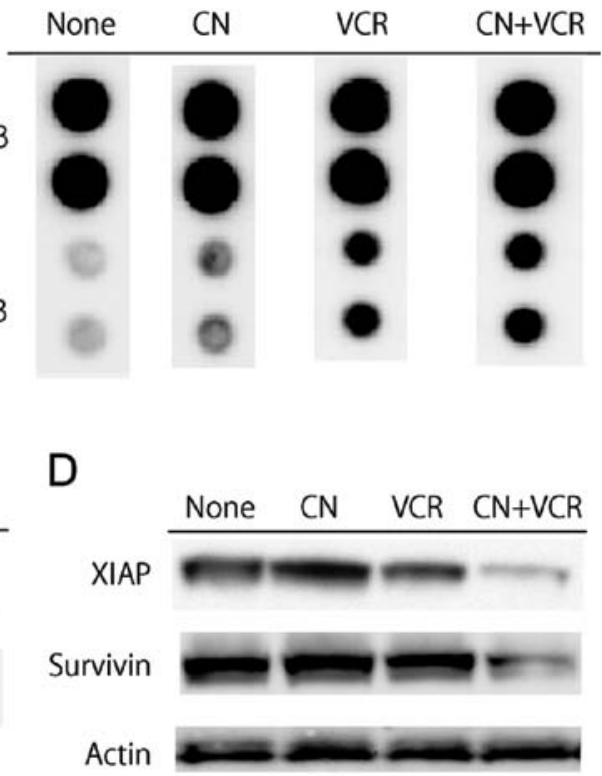

Figure 2. Induction of apoptosis and expression of apoptosis-associated proteins by cotylenin A (CN) and vincristine (VCR). (A) Expression of Annexin V. RPMI-8226 cells were treated with $2 \mathrm{ng} / \mathrm{ml}$ vincristine and $/$ or $2 \mu \mathrm{g} / \mathrm{ml}$ cotylenin A for 3 days. The values are the means \pm SD of four determinations. Protein profiler array (B and C) and western blotting (D). Cells were treated with $2 \mathrm{ng} / \mathrm{ml}$ vincristine and/or $2 \mu \mathrm{g} / \mathrm{ml}$ cotylenin A for 2 days.

Table I.Potentiation of the growth-inhibitory activities of various anticancer agents in RPM-I8226 myeloma cells by cotylenin A.

\begin{tabular}{lccc}
\hline & \multicolumn{2}{c}{ Growth inhibition $\left(\mathrm{IC}_{50}\right)$} & \\
\cline { 2 - 3 } $\begin{array}{l}\text { Anticancer agent } \\
\text { (ng/ml) }\end{array}$ & - Cotylenin A & + Cotylenin A & Ratio (-/+) \\
\hline Doxorubicin & $5.5 \pm 0.6$ & $5.3 \pm 0.5$ & 1.03 \\
Cisplatin & $246 \pm 30.2$ & $237 \pm 28.4$ & 1.03 \\
Camptotecin & $1.42 \pm 0.16$ & $1.38 \pm 0.14$ & 1.03 \\
Methotrexate & $2.76 \pm 0.3$ & $1.81 \pm 0.2$ & 1.52 \\
Gemcitabine & $4.3 \pm 0.4$ & $3.1 \pm 0.3$ & 1.39 \\
5-Fluorouracil & $56.5 \pm 5.1$ & $57.8 \pm 6.3$ & 0.98 \\
Vincristine & $6.3 \pm 0.6$ & $1.6 \pm 0.1$ & 3.94 \\
Vinblastine & $0.91 \pm 0.11$ & $0.42 \pm 0.05$ & 2.17 \\
Paclitaxel & $16.4 \pm 1.9$ & $7.7 \pm 0.9$ & 2.13 \\
\hline
\end{tabular}

Ratio $(-/+), \mathrm{IC}_{50}$ without cotylenin A: $\mathrm{IC}_{50}$ with cotylenin A. The values are the mean $\pm \mathrm{SD}$ of four determinations.

of vincristine with cotylenin $A$ that were isoeffective $\left(\mathrm{IC}_{50}\right.$ : concentration of the drug required for $50 \%$ inhibition of cell growth) for inhibition of the proliferation of RPMI- 8226 cells. These isoboles indicate that the combination of these drugs had synergistic effects. The synergistic effects of cotylenin A and vincristine were also observed in other myeloma cell lines, although the different myeloma cell lines had different sensitivities to vincristine (Fig. 1C-F).

Induction of apoptosis in RPMI-8226 cells treated with cotylenin A and vincristine. When RPMI-8226 cells were exposed to $2 \mathrm{ng} / \mathrm{ml}$ vincristine in the presence of cotylenin A for 4 days, a morphological analysis showed shriveled cells, chromatin condensation, nuclear fragmentation and cytoplasmic blebbing, although these morphological changes were hardly observed in cells treated with $2 \mathrm{ng} / \mathrm{ml}$ vincristine alone. The induction of apoptosis was confirmed by an analysis of the DNA histogram (cells in sub-G1 phase) and the expression of Annexin V (Table II, Fig. 2A). A proteome profiler analysis of myeloma cells was performed to elucidate the effects of the combined treatment on apoptotic pathways.

The expression of cleaved caspase- 3 was increased in treatment with vincristine and further enhanced by cotylenin A (Fig. 2B). Significant alterations in protein expression were noted in cells treated with cotylenin A and vincristine: the levels of anti-apoptotic proteins such as cIAP, XIAP and survivin were markedly decreased (Fig. 2C). These changes were confirmed by Western blot analysis (Fig. 2D). The expression of anti-apoptotic proteins, $\mathrm{Bcl}-2$ or $\mathrm{Bcl}-\mathrm{X}$, was hardly affected by treatment.

Morphologic changes and reduction of invasive activity in cells treated with cotylenin A. When RPMI-8226 cells were cultured on a Matrigel-coated dish, most of the cells had elongated shapes and were migrating. However, treatment with a low concentration of cotylenin A $(0.6 \mu \mathrm{g} / \mathrm{ml})$ induced morphological changes without inhibiting growth. Most of the treated cells had round shapes within 3 days (Fig. 3A). An invasion assay revealed that cotylenin A effectively inhibited the invasive activity of RPMI-8226 cells without inhibiting growth (Fig. 3B).

Inhibition of colony formation and expression of pluripotencyassociated transcription factors by cotylenin A. A colony-forming assay indicated that cotylenin A preferentially inhibited 
A Cotylenin A

$(0.6 \mu \mathrm{g} / \mathrm{ml})$

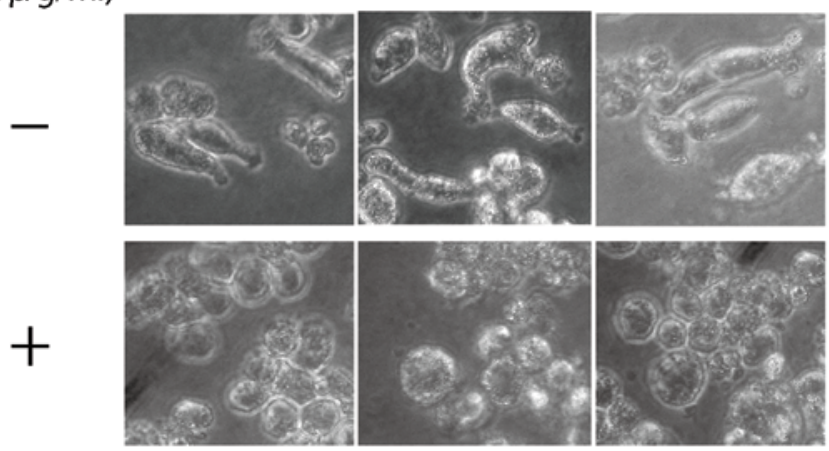

C

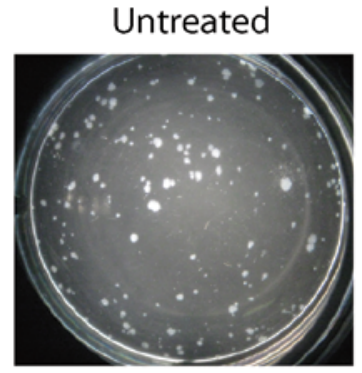

D

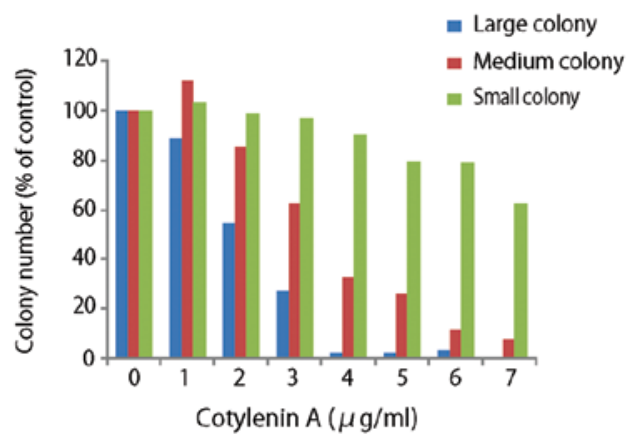

$\mathrm{F}$

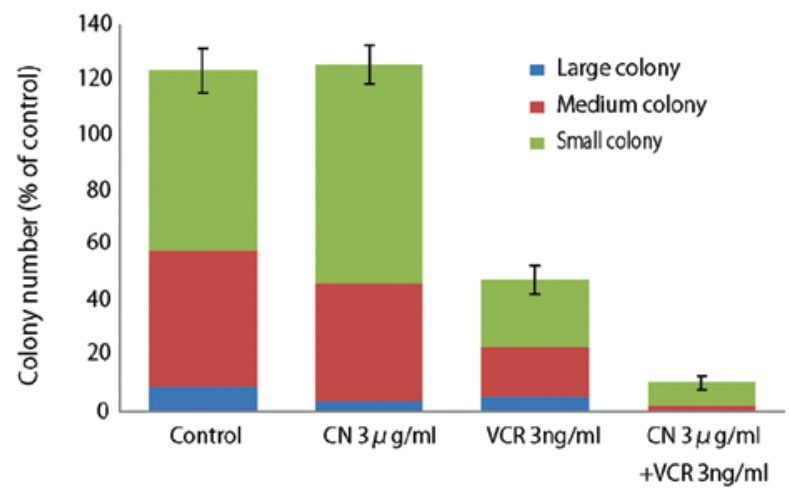

CN-treated

$E$

G
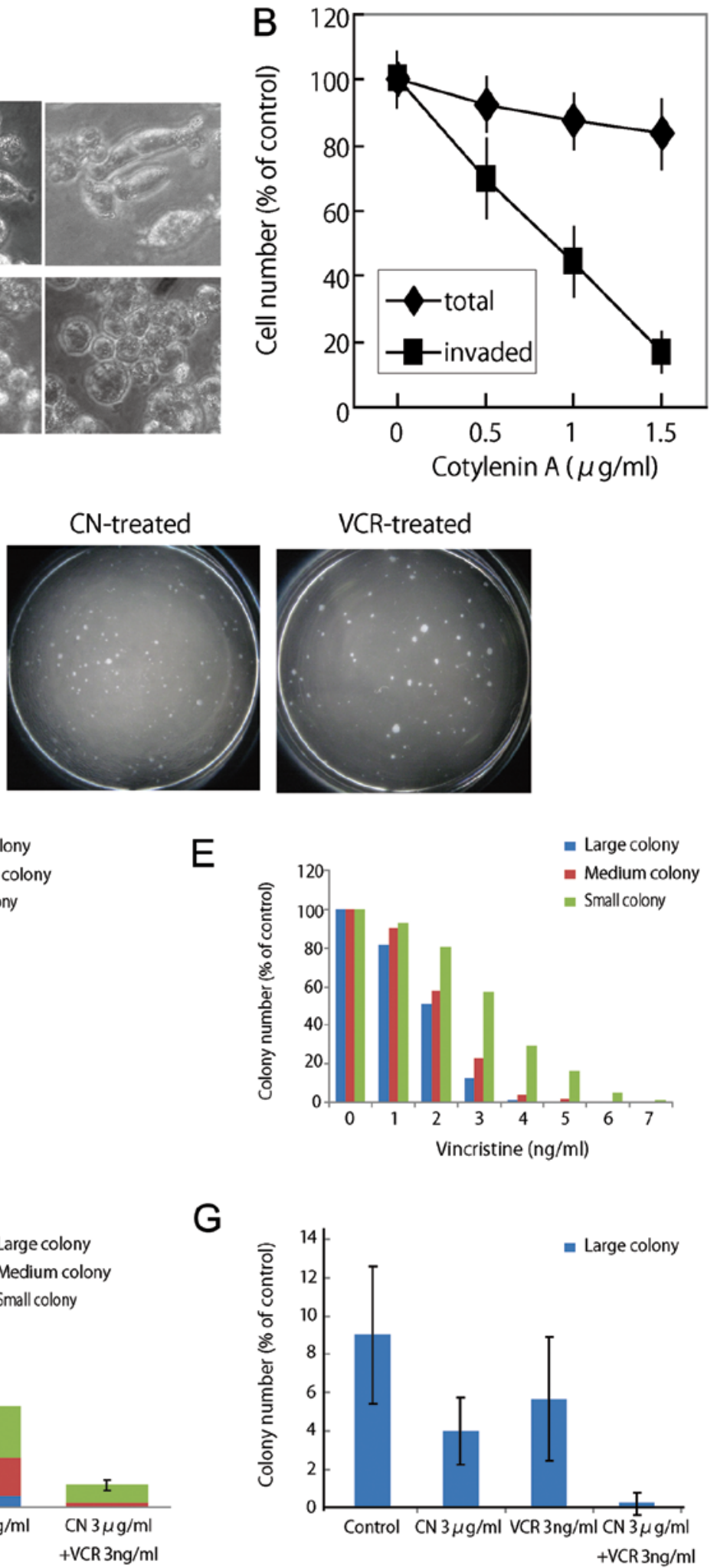

Figure 3. Effects of cotylenin A on morphology and invasion of RPMI-8226 cells. (A) Morphologic changes in cells treated with cotylenin A for 3 days on

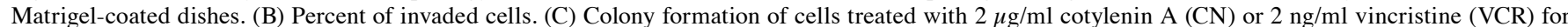
10 days. (D) Effects of cotylenin A on the formation of large, medium and small colonies. (E) Effects of vincristine on the formation of large, medium and small colonies. The values are the means of 10 determinations. ( $\mathrm{F}$ and G) Combined effects of cotylenin A $(3 \mu \mathrm{g} / \mathrm{ml})$ and vincristine $(3 \mathrm{ng} / \mathrm{ml})$ on colony formation by RPMI-8226 cells cultured for 14 days. (F) Total colonies, (G) large colonies. The values are the means \pm SD of six determinations.

the formation of large colonies whereas vincristine similarly inhibited the formation of colonies of different sizes (Fig. 3C-E). The combined treatment with cotylenin A and vincristine effectively suppressed colony formation by myeloma cells (Fig. 3F), and especially the formation of large colonies (Fig. 3G).

Since Wnt/ $\beta$-catenin signaling molecules have been implicated in the maintenance of pluripotency-associated 
Table II. Effects of cotylenin A and vincristine on apoptosis of myeloma cells.

\begin{tabular}{lc}
\hline Treatment & Apoptosis (\% of cells in sub-G1 phase) \\
\hline None & $6.1 \pm 1.2$ \\
Cotylenin A $(\mu \mathrm{g} / \mathrm{ml})$ & \\
1 & $7.3 \pm 1.3$ \\
2 & $7.7 \pm 1.8$ \\
3 & $9.6 \pm 1.7$ \\
6 & $12.9 \pm 2.3$ \\
Vincristine $(\mathrm{ng} / \mathrm{ml})$ & \\
1 & $7.1 \pm 1.9$ \\
2 & $12.1 \pm 2.8$ \\
3 & $20.9 \pm 3.2$ \\
6 & $64.4 \pm 8.9$ \\
Cotylenin A $(2 \mu \mathrm{g} / \mathrm{ml})$ and & $87.5 \pm 9.6$ \\
Vincristine $(2 \mathrm{ng} / \mathrm{ml})$ & \\
\hline
\end{tabular}

RPMI-8226 cells were treated with cotylenin A and/or vincristine for 3 days. The values are the mean $\pm \mathrm{SD}$ of three determinations.

transcription factors (16), we evaluated the mRNA expression of $\beta$-catenin as well as the mRNA expression of pluripotencyassociated transcription factor (Fig. 4A and B). Expression of Sox 2 mRNA was significantly suppressed by treatment with cotylenin A. The reduction of Sox 2 mRNA expression was observed within $24 \mathrm{~h}$ (Fig. 4C).

Effect of vincristine or doxorubicin on autophagy induced by cotylenin A. Autophagy is a survival pathway that is responsible for the breakdown of damaged organelles and protein aggregates, although there is an ongoing controversy regarding whether the autophagy pathway primarily represents a prosurvival or pro-cell death mechanism with cancer therapy (17). Microtubules are required for autophagosomal biogenesis and degradation, and vinca alkaloids disrupt autophagosome maturation/degradation by preventing the movement of autophagosomes and their fusion with lysosomes (18). Several studies have demonstrated that the treatment of cancers with agents that induce autophagy in combination with agents that block autophagosome maturation/degradation results in synergistic apoptotic cell death (19-21). Myeloma cells require a basal level of autophagy for survival and the pharmacologic or genetic inhibition of autophagy caused myeloma cells to die (22). Therefore, we examined the effects of vincristine and doxorubicin on autophagic processes to understand how cotylenin A preferentially sensitizes myeloma cells to vincristine.

As described above, treatment with cotylenin A alone inhibited cell growth in a concentration-dependent manner, but did not significantly induce apoptosis. Since cotylenin A might induce autophagy in RPMI-8226 cells, we examined the levels of LC3-I and -II in cells treated with cotylenin A. Upon the initiation of autophagy, LC3 relocates from the cytosol to autophagosome membranes, where it plays a role in autophagosome enlargement, and cytosolic LC3 (LC3-I, $18 \mathrm{kDa}$ ) undergoes $\mathrm{C}$-terminal proteolytic processing to a $16 \mathrm{kDa}$ isoform, LC3-II. Fig. 4D shows that cotylenin A reduced the accumulation of LC3-I in a dose-dependent manner. This finding suggests that cotylenin A induced autophagosomes. Vincristine also induced the accumulation of LC3-II, whereas doxorubicin hardly affected the accumulation of LC3-II (Fig. 4E and G). Cells treated with cotylenin A and vincristine showed a synergistic increase in the levels of LC3-II compared to those treated with either of the agents alone (Fig. 4E). A synergistic increase was not observed in cells treated with cotylenin A and doxorubicin (Fig. 4G). p62 protein is a marker for autophagic flux, since the autophagy pathway normally degrades this protein. The accelerated degradation of $\mathrm{p} 62$ protein was also found in response to the combination treatment (Fig. 4F). These results indicate that there is a significant difference between the autophagic responses to vincristine and doxorubicin.

Effects of pre-and post-treatment with cotylenin A and vincristine on the growth of myeloma cells. To determine whether simultaneous treatment gives the best results, we examined the effects of pre- and post-treatment with cotylenin A on the vincristine-induced inhibition of the growth of RPMI-8226 cells. The results may provide useful information regarding the best schedule for combined treatment with cotylenin A and vincristine against xenografts of human myeloma cells. For pretreatment, cells were treated with $2 \mu \mathrm{g} / \mathrm{ml}$ of cotylenin A for 3 days, washed in fresh medium, and incubated with $2 \mathrm{ng} / \mathrm{ml}$ of vincristine for 3 days. For posttreatment, cells were treated with $2 \mathrm{ng} / \mathrm{ml}$ of vincristine for 3 days and then with $2 \mu \mathrm{g} / \mathrm{ml}$ of cotylenin A. Fig. 5A shows that simultaneous treatment is more effective than pre- or post-treatment with cotylenin A, although pretreatment with cotylenin A gave better results than posttreatment. Similar results were obtained when other myeloma cells were treated with cotylenin A and vincristine.

Effects of cotylenin A and vincristine on in vivo growth of myeloma cells as xenografts. To determine the potential for cotylenin A in treating myeloma, we treated KMS-26 xenograft-bearing SCID mice with cotylenin A alone or in combination with vincristine. We treated mice with cotylenin A at $5 \mathrm{mg} / \mathrm{kg}$ body weight, as described previously $(4,6)$. This dose of cotylenin A was well-tolerated without a loss of body weight. Cotylenin A alone inhibited the growth of KMS-26 xenograft tumors with a day 21 (end of treatment period) $\mathrm{T} / \mathrm{C}$ value (the mean volume of xenograft tumor in treated mice/that in untreated control mice) of $76.8 \%$ (Fig. 5B and C). Our in vitro studies (Fig. 5A) suggest that simultaneous treatment with cotylenin $\mathrm{A}$ and vincristine is more effective therapeutically than treatment with vincristine alone. Therefore, we examined the combined effects of cotylenin A and vincristine on the in vivo growth of KMS-26 cells (Fig. 5B and $\mathrm{C}$ ). Vincristine alone greatly inhibited tumor growth with a T/C value of $22.7 \%$. Combined treatment caused tumor stasis at day 21 with a T/C value of $4.6 \%$. In this model, cotylenin A exhibited single-agent activity in xenografts of KMS-26 cells, along with increased antitumor effects in combination with vincristine. A statistical analysis revealed that the difference was significant $(P<0.05$, versus control). The effects of single-agent treatments were not statistically significant in this 
A
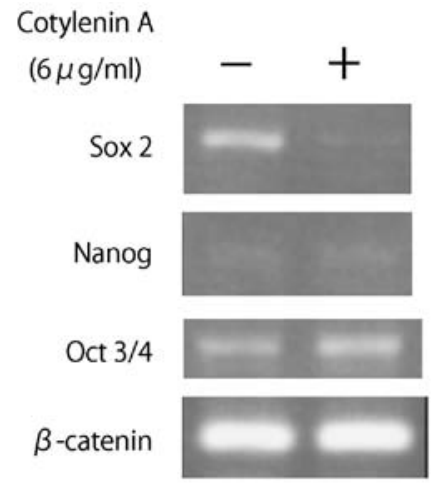

Bmi-1

GAPDH

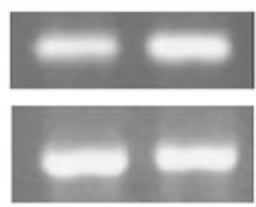

B Cotylenin A

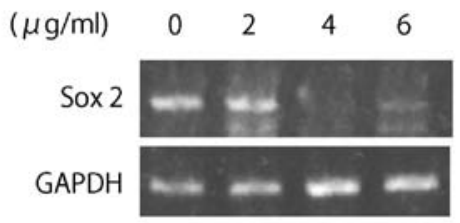

C

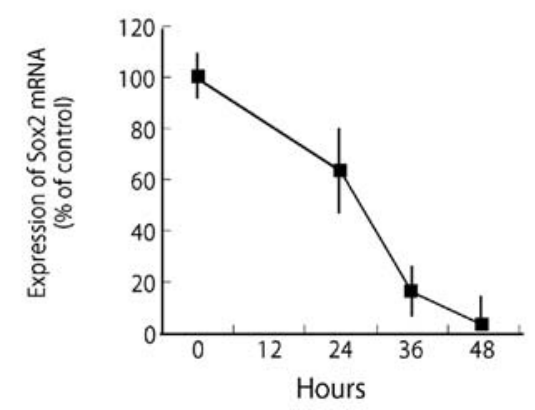

E

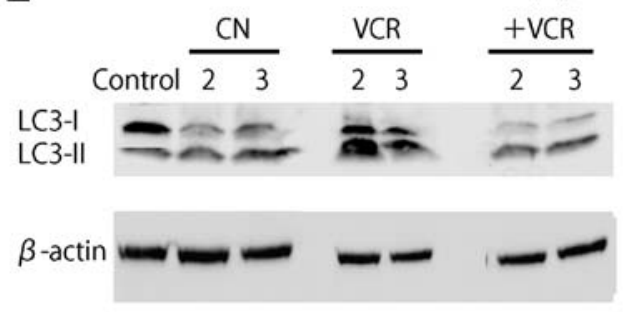

G

$\mathrm{F}$

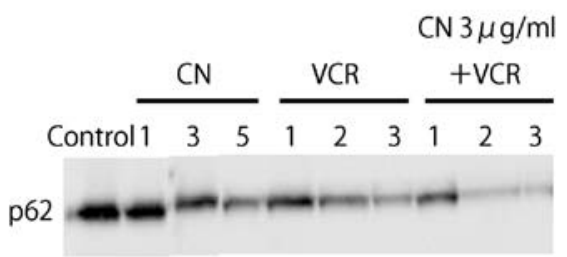
$\mathrm{CN} 3 \mu \mathrm{g} / \mathrm{ml}$

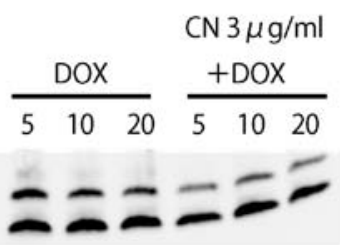

Figure 4. Effects of cotylenin A on gene expression of $\beta$-catenin and pluripotency-associated transcription factors. (A) RPMI-8226 cells were treated with $6 \mu \mathrm{g} / \mathrm{ml}$ cotylenin A for 3 days. (B) Expression of Sox-2 mRNA in cells treated with various concentrations of cotylenin A for 2 days. (C) Time-course of Sox 2 mRNA expression in RPMI-8226 cells treated with $4 \mu \mathrm{g} / \mathrm{ml}$ cotylenin A. The values are the means \pm SD of three determinations. (D) LC3-I and LC3-II levels in RPMI-8226 cells treated with cotylenin A for $48 \mathrm{~h}$. (E) LC3-I and LC3-II levels in RPMI-8226 cells treated with cotylenin A (CN) ( $\mu \mathrm{g} / \mathrm{ml})$ and/or vincristine (VCR) $(\mathrm{ng} / \mathrm{ml})$ for $48 \mathrm{~h}$. (F) Effects of CN $(\mu \mathrm{g} / \mathrm{ml})$ and $/$ or VCR $(\mathrm{ng} / \mathrm{ml})$ on the expression of p62 protein. (G) LC3-I and LC3-II levels in RPMI-8226 cells treated with cotylenin A $(\mathrm{CN})(\mu \mathrm{g} / \mathrm{ml})$ and/or doxorubicin (DOX) $(\mathrm{ng} / \mathrm{ml})$ for $48 \mathrm{~h}$.

experiment among the 4 groups. Vincristine caused significant decrease in the body weight of the mice. However, the weight loss in the combined-treated group was lower than that in mice treated with vincristine alone (Fig. 5D).

\section{Discussion}

The phenotypes of cancer stem cells in multiple myeloma are still controversial $(23,24)$. In the present study, we demonstrated that cotylenin A preferentially inhibited the population that formed large colonies, suggesting that cells have high selfrenewal activity. The pluripotency-associated transcription factor Sox 2 was effectively down-regulated by treatment with cotylenin A. Expression of Sox 2 was important for the development of tumors, as shown in vivo experiments. Spisek et al reported that Sox 2 was highly expressed in the clonogenic compartment of plasma cells and that anti-Sox $2 \mathrm{~T}$ cells help to prevent disease progression in patients with monoclonal gammopathy (25). These results suggest that cotylenin $\mathrm{A}$ is a useful drug for cancer stem cell-targeted therapy against multiple myeloma.

Multiple myeloma remains incurable for the vast majority of patients, which suggests that the cancer stem cells that mediate relapse are relatively resistant to chemotherapy. Cotylenin A effectively inhibits clonogenic growth and the expression of Sox 2 in myeloma cells. The inhibition of clonogenic growth was coupled with accelerated differentiation of the cells into mature $\mathrm{CD} 138^{+}$cells (26). Cotylenin A effectively and concentration-dependently decreased CD138cells in an RPMI-8226 cell population (data not shown). The sensitivity to vincristine was effectively enhanced by cotylenin A, and combined treatment with cotylenin A and vincristine significantly inhibited tumor growth in xenografts. Cotylenin A had no apparent effects on mice (body weight or behavior), and reduced the vincristine-induced toxicity in tumor-bearing mice. Vincristine is frequently used for the 

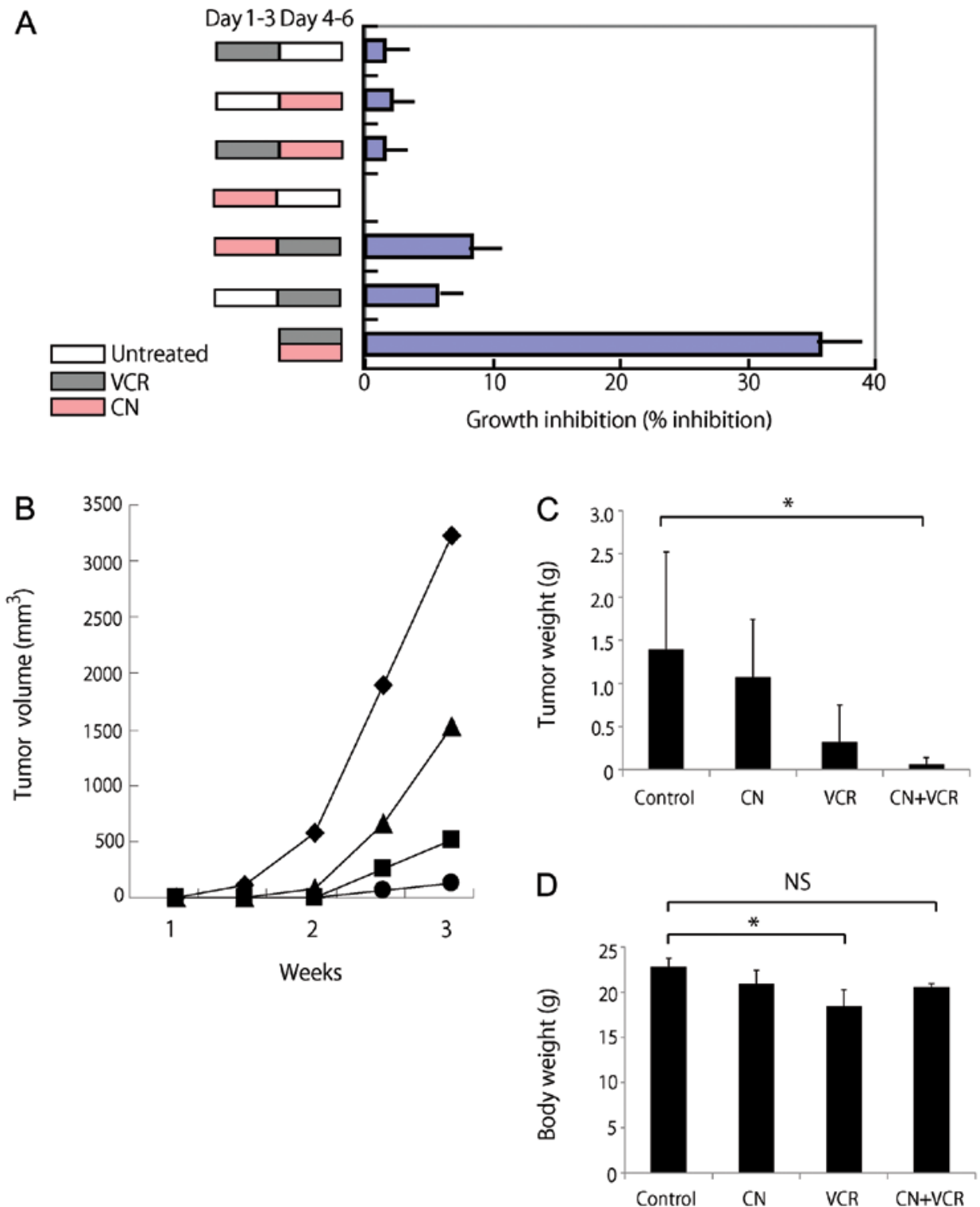

Figure 5. Simultaneous or concurrent treatment with cotylenin A and vincristine on the growth of myeloma cells. The effect of cotylenin A and vincristine in xenograft model. (A) Growth inhibition in RPMI-8226 cells treated with cotylenin A and vincristine. Cells were cultured for 3 days in the presence or absence of $2 \mu \mathrm{g} / \mathrm{ml}$ of cotylenin A or $2 \mathrm{ng} / \mathrm{ml}$ of vincristine. On day 3 , the cultures were washed with fresh medium and reincubated in the presence or absence of the same concentration of cotylenin A or vincristine. The values are the means \pm SD of four determinations. (B) Effects of cotylenin A and vincristine on the growth of KMS-26 cells as xenografts. Mice received intraperitoneal injections of cotylenin A ( $\mathbf{\Delta})$, vincristine ( $\mathbf{\square})$ and the combination of cotylenin A and vincristine (•) 3 times/week for 3 weeks. ( $\bullet$ Untreated mice. (C) Tumor weight at day 21. (D) Body weight at day 21. The values are the means \pm SD of 5 determinations. Data were analyzed by one-way analysis of variance and the Kruskal-Wallis test. "P<0.05; NS, not significant; CN, cotylenin A; VCR, vincristine.

treatment of multiple myeloma $(27,28)$. These results suggest that the combination of cotylenin A and vincristine could be useful for the treatment of multiple myeloma.

While cotylenin A significantly enhanced the sensitivity to vincristine and other microtubule-disturbing agents, cotylenin A did not affect the sensitivity to other anticancer agents such as doxorubicin, camptotecin, cisplatin, 5-fluorouracil, methotrexate and gemcitabine. These differences might be attributed to the effects on autophagic responses. Cotylenin A and vincristine concentration-dependently induced autophagy, and combined treatment with cotylenin $\mathrm{A}$ and vincristine further induced autophagy (formation of LC3-II and degradation of p62 protein). However, doxorubicin did not affect the autophagic responses, and did not enhance the autophagy induced by cotylenin A. Combined treatment with vincristine and cotylenin A also induced apoptosis (activation of caspase-3, accumulation of subG1 fraction and induction of Annexin V). Myeloma cells exhibit low-level autophagy under basal conditions, and uncontrolled autophagy may reduce cellular viability under some circumstances (29). Further studies will be needed to better understand the cell death induced by vincristine plus cotylenin $\mathrm{A}$.

A receptor of fusicoccins, including cotylenin $\mathrm{A}$, has been reported to be a member of a family of 14-3-3 proteins that are found in a huge array of signaling and regulatory pathways (30). The 14-3-3 proteins bind to discrete phosphoserine-containing motifs present in many signaling molecules. The 14-3-3 proteins are associated with dynamic nucleocytoplasmic shuttling. 
However, further studies will be needed to explain how the sensitization to vincristine is related to the effects of cotylenin A on the 14-3-3 signaling pathway.

The administration of cotylenin A significantly prolonged the survival of mice that had been inoculated with cells of the human promyelocytic leukemia cell line NB4 (4). Cotylenin A co-operatively inhibited tumor growth in xenografts with IFN $\alpha$ (6), rapamycin (9) or cetuximab (31). Treatment with cotylenin A had no apparent adverse effects on mice, and reduced the adverse effects of vincristine on tumor-bearing mice. A novel fusicoccin derivative, closely related to cotylenin A, significantly inhibited the growth of pancreatic cancer MIAPaCa-2 cells as xenografts without apparent adverse effects (32). These results suggest that 14-3-3 proteins may be novel targets in cancer therapy.

In conclusion, we found that cotylenin A and vincristine synergistically inhibited the growth of and induced apoptosis in myeloma cells in vitro and in vivo. Our results suggest that the combination of cotylenin A and vincristine may have therapeutic value in treating multiple myeloma.

\section{References}

1. Yamamoto-Yamaguchi Y, Yamada K, Ishii Y, Asahi KI, Tomoyasu S and Honma Y: Induction of the monocytic differentiation of myeloid leukaemia cells by cotylenin A, a plant growth regulator. Br J Haematol 112: 697-705, 2001.

2. Yamada K, Honma Y, Asahi KI, Sassa T, Hino KI and Tomoyasu S: Differentiation of human acute myeloid leukaemia cells in primary culture in response to cotylenin $\mathrm{A}$, a plant growth regulator. Br J Haematol 114: 814-821, 2001.

3. Honma Y and Cotylenin A: Cotylenin A - a plant growth regulator as a differentiation-inducing agent against myeloid leukemia. Leuk Lymphoma 43: 1169-1178, 2002.

4. Honma Y, Ishii Y, Sassa T and Asahi K: Treatment of human promyelocytic leukemia in the SCID mouse model with cotylenin A, an inducer of myelomonocytic differentiation of leukemia cells. Leuk Res 27: 1019-1025, 2003.

5. Honma Y and Akimoto M: Therapeutic strategy using phenotypic modulation of cancer cells by differentiation-inducing agents. Cancer Sci 98: 1643-1651, 2007.

6. Honma Y, Ishii Y, Yamamoto-Yamaguchi Y, Sassa T and Asahi K: Cotylenin A, a differentiation-inducing agent, and IFN-alpha cooperatively induce apoptosis and have an antitumor effect on human non-small cell lung carcinoma cells in nude mice. Cancer Res 63: 3659-3666, 2003.

7. Honma Y, Kasukabe T, Yamori T, Kato N and Sassa T: Antitumor effect of cotylenin A plus interferon- $\alpha$ : Possible therapeutic agents against ovary carcinoma. Gynecol Oncol 99: 680-688, 2005.

8. Sassa T, Tojyo T and Munakata K: Isolation of a new plant growth substance with cytokinin-like activity. Nature 227: 379, 1970.

9. Kasukabe T, Okabe-Kado J, Kato N, Sassa T and Honma Y: Effects of combined treatment with rapamycin and cotylenin A, a novel differentiation-inducing agent, on human breast carcinoma MCF-7 cells and xenografts. Breast Cancer Res 7: R1097-R1110, 2005.

10. Ishii Y, Hori Y, Sakai S and Honma Y: Control of differentiation and apoptosis of human myeloid leukemia cells by cytokinins and cytokinin nucleosides, plant redifferentiation-inducing hormones. Cell Growth Differ 13: 19-26, 2002.

11. Niitsu N, Higashihara M and Honma Y: The catalytic DNA topoisomerase II inhibitor ICRF-193 and all-trans retinoic acid cooperatively induce granulocytic differentiation of acute promyelocytic leukemia cells: Candidate drugs for chemodifferentiation therapy against acute promyelocytic leukemia. Exp Hematol 30: 1273-1282, 2002.

12. Ikegame A, Ozaki S, Tsuji D, et al: Small molecule antibody targeting HLA class I inhibits myeloma cancer stem cells by repressing pluripotency-associated transcription factors. Leukemia 26: 2124-2134, 2012.
13. Quesada JR, Alexanian R, Hawkins M, Barlogie B, Borden E, Itri L and Gutterman JU: Treatment of multiple myeloma with recombinant alpha-interferon. Blood 67: 275-278, 1986.

14. Mandelli F, Avvisati G, Amadori S, et al: Maintenance treatment with recombinant interferon alfa-2b in patients with multiple myeloma responding to conventional induction chemotherapy. $\mathrm{N}$ Engl J Med 322: 1430-1434, 1990.

15. Chou TC and Talalay P: Quantitative analysis of dose-effect relationships: The combined effects of multiple drugs or enzyme inhibitors. Adv Enzyme Regul 22: 27-55, 1984.

16. Marson A, Foreman R, Chevalier B, Bilodeau S, Kahn M, Young RA and Jaenisch R: Wnt signaling promotes reprogramming of somatic cells to pluripotency. Cell Stem Cell 3: 132-135, 2008.

17. White EJ, Martin V, Liu JL, Klein SR, Piya S, Gomez-Manzano C, Fueyo $\mathrm{J}$ and Jiang H: Autophagy regulation in cancer development and therapy. Am J Cancer Res 1: 362-372, 2011.

18. Xie R, Nguyen S, McKeehan WL and Liu L: Acetylated microtubules are required for fusion of autophagosomes with lysosomes. BMC Cell Biol 11: 89, 2010.

19. Marimpietri D, Brignole C, Nico B, et al: Combined therapeutic effects of vinblastine and rapamycin on human neuroblastoma growth, apoptosis, and angiogenesis. Clin Cancer Res 13: 3977-3988, 2007.

20. Zhou Q, Lui VW, Lau CP, Cheng SH, Ng MH, Cai Y, Chan SL and Yeo W: Sustained antitumor activity by co-targeting mTOR and the microtubule with temsirolimus/vinblastine combination in hepatocellular carcinoma. Biochem Pharmacol 83: 1146-1158, 2012.

21. Adiseshaiah PP, Clogston JD, McLeland CB, et al: Synergistic combination therapy with nanoliposomal C6-ceramide and vinblastine is associated with autophagy dysfunction in hepatocarcinoma and colorectal cancer models. Cancer Lett 337: 254-265, 2013

22. Hoang B, Benavides A, Shi Y, Frost P and Lichtenstein A: Effect of autophagy on multiple myeloma cell viability. Mol Cancer Ther 8: 1974-1984, 2009.

23. Agarwal JR and Matsui W: Multiple myeloma: A paradigm for translation of the cancer stem cell hypothesis. Anticancer Agents Med Chem 10: 116-120, 2010.

24. Boucher K, Parquet N, Widen R, Shain K, Baz R, Alsina M, Koomen J, Anasetti C, Dalton W and Perez LE: Stemness of B-cell progenitors in multiple myeloma bone marrow. Clin Cancer Res 18: 6155-6168, 2012.

25. Spisek R, Kukreja A, Chen LC, et al: Frequent and specific immunity to the embryonal stem cell-associated antigen SOX2 in patients with monoclonal gammopathy. J Exp Med 204: 831-840, 2007.

26. Leung-Hagesteijn C, Erdmann N, Cheung G, Keats JJ, Stewart AK, Reece DE, Chung KC and Tiedemann RE: Xbplsnegative tumor B cells and pre-plasmablasts mediate therapeutic proteasome inhibitor resistance in multiple myeloma. Cancer Cell 24: 289-304, 2013.

27. Kumar A, Galeb S and Djulbegovic B: Treatment of patients with multiple myeloma: An overview of systematic reviews. Acta Haematol 125: 8-22, 2011.

28. Suzuki K: Current therapeutic strategy for multiple myeloma. Jpn J Clin Oncol 43: 116-124, 2013.

29. Galluzzi L, Vitale I, Abrams JM, et al: Molecular definitions of cell death subroutines: Recommendations of the Nomenclature Committee on Cell Death 2012. Cell Death Differ 19: 107-120, 2012.

30. Oecking $\mathrm{C}$, Eckerskorn $\mathrm{C}$ and Weiler EW: The fusicoccin receptor of plants is a member of the 14-3-3 superfamily of eukaryotic regulatory proteins. FEBS Lett 352: 163-166, 1994.

31. Molzan M, Kasper S, Röglin L, et al: Stabilization of physical RAF/14-3-3 interaction by cotylenin A as treatment strategy for RAS mutant cancers. ACS Chem Biol 8: 1869-1875, 2013.

32. Kawakami K, Hattori M, Inoue $\mathrm{T}$, et al: A novel fusicoccin derivative preferentially targets hypoxic tumor cells and inhibits tumor growth in xenografts. Anticancer Agents Med Chem 12: 791-800, 2012. 